\title{
ČESKÉ PLÁTNO, BRAZILSKÝ CUKR A PORTUGALSKÁ INKVIZICE. NA OKRAJ JEDNOHO RUKOPISU*
}

\author{
Simona Binková (Praha)
}

\begin{abstract}
Bohemian Linen, Brazilian Sugar and the Portuguese Inquisition. On the Margin of One Manuscript
Abstract: In the 18th-century Habsburg empire, Bohemian linen (and glass) was an important export article for trade within Europe as well as with overseas regions. The aims of this article are to explain briefly the general context of these commercial activities, tied to the Iberian Peninsula, and, in particular, to focus on little or completely unknown facts, namely the relation of the brothers František and Václav Sperling from Náchod to Portugal. The trade involved not only the actual exportation of linen and its innovative final chemical processing (bleaching) in Bohemia and in Portugal as well as the commencement of the importation of Brazilian raw sugar and its refinement in Bohemia, but also the associated problem of the integration of foreigners into a different environment, in this case the integration of Central Europeans (often a priori suspected of heresy) into the predominantly Catholic area of the Iberian Peninsula.
\end{abstract}

Keywords: Bohemian entrepreneurs in the 18th century - Bohemian linen production, export and chemical innovations - Brazilian sugar import and refineries in Bohemia - Portugal - Inquisition

Vývoz plátna a skla z českých zemí do Portugalska a Španělska se předpokládá už v době předcházející válkám o španělské dědictví (1701-1713/1714). V jejich průběhu čeští obchodníci mající již dřive své zájmy na Iberském poloostrově podpořili finančně aktivity habsburského pretendenta na španělský trůn, rakouského arcivévody Karla (budoucího císaře Svaté rríše rímské Karla VI.). ${ }^{1} \mathrm{~V}$ onom konfliktu Portugalsko (po boku Velké Británie a dalších zemí) tvořilo součást prohabsburské aliance proti francouzským Bourbonům. Toto sblížení mezi Portugalskem, částí Španělského království (především Katalánska) a říše, i když v následujících letech na poli zahraniční politiky nenaplněné, bylo $\mathrm{v}$ dalších oblastech patrné prakticky po celé 18 . století. Konkrétně v Portugalsku byla velkou podporovatelkou vzájemných vztahů se zeměmi střední Evropy Karlova sestra, arcivévodkyně Marie Anna (Marianna) provdaná V roce 1708 za portugalského krále Jana V. (1707-1750). Za svého života (zemřela roku 1754) zavedla v Portugalsku úctu k českému světci sv. Janu Nepomuckému, udržovala kontakt s jezuitskými misionáři ze střední Evropy i českých zemí odcházejících do zámořských misií v Brazílii i Asii. Také její osobní zpovědník a část služebnictva pocházeli ze zemí jejího původu. ${ }^{2}$

Ve stejné době můžeme pozorovat také snahy o navázání či prohloubení obchodních vztahů mezi Portugalskem (a jeho koloniemi) a habsburskou říší (včetně českých zemí) na nejrůznějších úrovních: oficiální, polooficiální i soukromé. Šlo o sít osobních, ale také politických zájmů, které v některých př́padech měly dosah až do počátku 19. století.

V první třetině 18 . století poutá pozornost několik iniciativ Portugalce Luise Maciela, který mimo jiné nabízel spolupráci rakouské obchodní společnosti v Terstu a později i Ostendské společnosti, která ovšem neměla dlouhého trvání. ${ }^{3}$ Prostředníka svých návrhů ještě počátkem 30. let hledal v osobě Manuela Telese da Silva (1696-1771), původně příslušníka portugalské šlechty, ale později zakladatele rakouského hraběcího rodu Silva Tarouca usedlého také v českých zemích. ${ }^{4}$ Maciel nabízel obchod s tabákem, čokoládou, kávou a cukrem (výměnou za plátno, kovy a jiné zboží) přes Hamburk a dále po Labi do střední Evropy

\footnotetext{
* Tato práce vznikla za podpory projektu „Kreativita a adaptabilita jako předpoklad úspěchu Evropy v propojeném světě“, reg. č.: CZ.02.1.01/0.0/0.0/ 16_019/0000734, financovaného z Evropského fondu pro regionální rozvoj.

${ }^{1}$ Srov. POLIŠENSKÝ 1978a, k tomuto tématu zvláště s. 14-15. Dále, mimo jiné, BAĎURA 1964, zvláště s. 74nn. Česká verze viz BAĎURA 2005.

2 K diplomatické misi vedoucí ke sňatku srov. POLIŠENSKÝ 1978a, s. 14. Podrobněji POLIŠENSKÝ 1978b. Pro širší kontext a zapojení církevních kruhů viz např. přehledově BINKOVÁ 1987, zvláště s. 138-139. Podrobněji ZAVADILOVÁ 2001.

3 Tato společnost založená nejprve jako soukromá získala záhy podporu císaře Karla VI. jako Rakouská východoindická (nebo také Všeobecná c. a k. indická) společnost působící v důsledku Rastattského míru z roku 1714 v nedávno získaném tzv. Rakouském (do té doby Španělském) Nizozemí. Podrobněji viz WANNER 2008a a WANNER 2008b.

${ }^{4}$ Syn portugalského vyslance ve Vídni v letech 1726-1738 João Gomese da Silva, hraběte Tarouca. Manuel byl př́telem Evžena Savojského a oblíbencem Karla VI., později rádcem jeho dcery Marie Terezie. Srov. např. SILVA-TAROUCA 1899; z jiného úhlu pohledu nověji ŠTĚPÁNEK 2015.
} 
a Vídně, případně dál do Itálie. Jiná větev měla napojit Slezsko a Polsko a další vést po Dunaji až do turecké říše. Žádný z těchto plánů se však nejspíše nerealizoval. ${ }^{5}$

Naproti tomu v poslední čtvrtině 18 . století jsme svědky již uskutečněných podnikatelských aktivit $\mathrm{v}$ oblasti obchodu s brazilským nerafinovaným třtinovým cukrem, zasílaným z Bahie, Rio de Janeira, Pernambuka a Paraíby do Portugalska, odkud byl přeprodáván dál. ${ }^{6}$

První rafinerie cukru ze zámoří byla v Čechách založena roku 1787 jako akciová společnost $(K . K$. privilegierte böhmische Zucker-Raffinerie) c. a k. obchodním radou Josephem de Souvaigne ve zrušeném cisterciáckém klášteře ve Zbraslavi u Prahy. Stejný muž stál již v čele podobných podniků v Terstu, Vídni, Klosterneuburgu a Šoproni. Císař Josef II. podpořil společnost uvalením vysokých cel na dovoz konkurenčního cukru z ciziny do Čech a plánoval i obnovení zákazu jeho dovozu zavedeného už Marií Terezií. ${ }^{7}$ Přes počáteční rozkvět výroby však vzhledem $\mathrm{k}$ růstu cen meziproduktu v důsledku válek za nezávislost Haiti rafinerie nakonec roku 1803 zkrachovala. Teprve roku 1812 nalezla nového vlastníka: Antonína Richtera staršího. Po různých peripetiích byl od počátku 30. let třtinový cukr rafinovaný na Zbraslavi postupně nahrazen cukrem řepným. ${ }^{8}$

V pořadí druhá rafinerie třtinového cukru v Čechách byla založena ve stejném roce 1787 v Novém Dvoře (místě, které se dříve nazývalo také Jakubův Dvůr, nedaleko Náchoda a České Skalice). Podnikatelem byl v tomto případě František Sperling (Vrabec), rodák z Náchoda. ${ }^{9}$ Jeho zásluhou se tam už od roku 1766 slibně rozvíjelo plátenictví. Sperling zprvu do zahraničí vyvážel plátno nezpracované, ale později zrrídil v Náchodě vlastní bělidlo a jako chemika získal na léta 1791-1795 Christiana Polykarpa Erxlebena (1765-1831), ${ }^{10}$ spolupracovníka barona Ignáce Antonína Borna, vynálezce tzv. rychlého, chemického nebo umělého bělení. Znalost této nové metody měl Erxleben sdílet nejen s Františkem Sperlingem, ale i s jeho bratrem Václavem, který tou dobou dlel právě v Čechách. ${ }^{11} \mathrm{~K}$ této otázce se vrátíme ještě níže.

Ve svých začátcích procestoval František Sperling všechny hlavní evropské průmyslově vyspělé země. Cestoval také do Španělska a Portugalska, kde navázal obchodní kontakty, ale vyvinul rovněž snahu seznámit se $\mathrm{s}$ technologií rafinace cukru. Tehdy získal licenci portugalského krále k provozování obchodu s českým plátnem výměnou za americký cukr na dobu 10 let s osvobozením od celních poplatků. K dosažení tohoto cíle přivedl s sebou do Čech odborníka na zpracování cukru, mistra Dominga Gonçalvese de Santa Marta, nositele povolení zakládat vlastní rafinerie, které mu udělil tehdejší státní sekretář markýz de Pombal. ${ }^{12}$

Cukrovar v Novém Dvoře zkrachoval už v roce 1798 v důsledku finančních problémů poté, co ztroskotala lod', která přivážela ze zámoří již zaplacenou surovinu. ${ }^{13}$

František Sperling spolupracoval v těchto podnikatelských aktivitách (prokazatelně alespoň do jisté míry) se svým mladším bratrem Václavem, který až doposud nebyl předmětem zájmu české (ale ani portugalské) historiografie. ${ }^{14}$ Přitom $\mathrm{z}$ archivních dokumentů i dobové literatury lze doložit, že se usadil v Portugalsku nedaleko města Leirie, kde vedl manufakturu na tkaní a bělení plátna.

Nejstarší mnou zachycená reference o Václavu Sperlingovi v tištěné literatuře se vztahuje k roku 1791, kdy jej již uvedený Erxleben zmiňuje v souvislosti se svým působením v Náchodě. Novou metodu bělení měl - na jeho žádost a náklady - předvést a zavést u podnikatele Františka Sperlinga, za př́tomnosti jeho bratra Václava, ,usedlého v Portugalsku, ale tehdy pobývajícího v Čechách [...], aby týž mohl podle této metody provozovat bělení v Portugalsku, $k$ čemuž potom skutečně v Leirii došlo ". ${ }^{15}$ Kromě (s největší pravděpodobností osobního) seznámení s Václavem Sperlingem v Náchodě měl Erxleben v době vydání svého odborného pojednání (1812) už i tiskem zprostředkovaný prŕístup $\mathrm{k}$ informacím o jeho dalším působení. V citovaném odstavci totiž odkazuje na Neueste Länder- und Völkerkunde... (1. díl, 1806) a heslo Leiria, kde se můžeme dočíst: ,Sedm čtvrtmílí od města [Leirie] založil před několika lety Němec jménem Sperling umělé bělidlo, které už ale opět zaniklo. "16 Oproti jiným stejně stručným zmínkám je zde navíc pouze informace o brzkém zániku zařízení.

Václavovo portugalské podnikání dokládá z vlastní cestovatelské zkušenosti významný německý př́rodovědec a botanik Heinrich Friedrich Link (1767-1851). Působil jako profesor na univerzitách v Göttingenu, Rostocku, Vratislavi a Berlíně. V letech 1797 až 1799 navštívil Francii, Španělsko a Portugalsko spolu s dalším německým přírodovědcem Johannem Centuriem von Hoffmannseggem (1766-1849).

\footnotetext{
${ }^{5}$ Tato osobnost a její celkové aktivity nebyly ještě podrobně zdokumentovány, přestože byla iniciátorem řady obchodních projektů. Zatím se zdá, že byly vesměs neúspěšné. Výjimkou ve zpracovanosti jsou dokumenty obsažené v MZA (dř́ve SOA Brno), fond G 445, Rodinný archiv SylvaTaroucců, karton 20, lit. M, dopisy Luise Maciela, ff. 271-284. Srov. mimo jiné BALCÁREK 1982; BALCÁREK 1984. Nejnověji BINKOVÁ 2018, zvláště s. 12-13.

${ }^{6} \mathrm{~K}$ této problematice srov. RIEGGER 1787, s. 842.

${ }^{7}$ LIPPMANN 1890, s. 336.

${ }^{8}$ FRONĚK 2008; NYPLOVÁ 1950

${ }^{9}$ Srov. PTÁČEK 1999; PTÁČEK 2012; NEUMANN 1891, s. 79-80; ŘíHA 1940, s. 133.

${ }^{10}$ SEKOTOVÁ 1976

${ }^{11}$ ČÁP 1995. Př́mé dobové svědectví viz ERXLEBEN 1812, s. 69.

${ }^{12}$ K tomu blíže RIEGGER 1787, s. 844-845. Srov. také OPATRNÝ 1995, zde s. 228-230.

${ }^{13}$ Srov. např. NEUMANN 1891, s. 79-80.

${ }^{14} \mathrm{Na}$ jeho osobu upozornila BINKOVÁ 2017.

${ }^{15}$ ERXLEBEN 1812, s. 69: ,, [...] und dem in Portugal ansässigen, aber damahls in Böhmen anwesenden Bruder desselben, Herren Wenzel Sperling, in diesem Verfahren practischen Unterricht zu ertheilen, damit derselbe in Portugal nach dieser Methode bleichen könne, was nachher wirklich zu Leiria geschehen ist. “

${ }^{16}$ EHRMANN 1806, s. 178, heslo 11: Leiria: , , [...] Sieben Viertelmeilen von der Stadt [Leiria] hatte vor einigen Jahren ein Teutscher, Namens Sperling, eine künstliche Bleiche angelegt, die aber wieder eingegangen ist. "Leiria je v tomto zeměpisném spise jedním ze dvou tuctů lokalit hodných zmínky v kraji Estremadura, kam spadá i Lisabon a jeho okolí.
} 
Jejich společným dílem se stal rozsáhlý popis portugalské květeny. ${ }^{17}$ Pro naše téma jsou však podstatnější cestopisné zápisky vydané Linkem nejprve německy jako Bemerkungen auf einer Reise durch Frankreich, Spanien und vorzüglich Portugal (1801-1804). ${ }^{18}$ O Sperlingovi se zmiňuje na dvou místech. Ve druhém svazku můžeme číst: „,U Leirie založil tehdy Němec jménem Sperling továrnu na bělení za pomoci překyselené kyseliny solné [= chlóru ${ }^{19}$. Ukázal mi některá zařizení, avšak to nejdůležitějši ukázat nechtěl, nebot' tvrdil, že tam zavedl speciální vybaveni. Vysvětlil, že válka jej nutí podnik zavrít, a jak jsem se doslechl, brzy nato továrna skončila. Dopustil se možná chyby mnoha podnikateli̊, kteři začali s príliš malým kapitálem. Jak nám vyprávěl, byl kdysi v nebezpeči dostat se do rukou inkvizice. S německým elánem se totiž často obracel ke slunci, aby mu při bělení bylo přiznivé, což někdo udal biskupovi jako modlářství. Ten však, Don Manoel de Aguiar, ${ }^{20}$ byl príliš rozumný, než aby ho za to obvinil, a spokojil se hned s jeho omluvou. "21

Ve třetím svazku už jen doplňuje: , Továrna na bělení u Leirie, založená Němcem Sperlingem, nejen že už před časem skončila, ale její zakladatel byl dokonce vypovězen ze zemé. "22

Cestopis vyšel záhy i v anglickém ${ }^{23}$ a francouzském překladu, ${ }^{24}$ informace $\mathrm{V}$ něm obsažené byly tedy bezprostředně k dispozici ve všech důležitých evropských jazycích. (A nově také v moderní edici v portugalštině. ${ }^{25}$ )

Další, jen velmi kusá a v podstatě identická zmínka následovala ještě v Allgemeine geographische Ephemeriden (1804): , Továrna na bělení u Leirie, založená Němcem jménem Sperling, nejen že už před časem zanikla, avšak jeji zakladatel byl také ze zemé vykázán. "26

Bližší - i základní životopisné - údaje vyčteme ale z archivního materiálu dochovaného v portugalském Národním archivu. Jde o ,Spis proti Václavu Superllingovi [sic, recte: Sperlingovi], jenž má továrnu blízko města Leirie“. Proces probíhal od konce roku 1795 do poloviny roku 1796. Přesněji od 23. 12. 1795 do 18. 6. 1796. ${ }^{27}$
Dokument má charakteristický obsah a strukturu inkvizičního spisu. Na počátku stojí obvinění (na základě udání), čeho se obviněný měl dopustit (kacířské názory: mimo jiné v otázce Neposkvrněného početí Panny Marie a Ježíšových sourozenců; rouhání; provinění proti Desateru: jedinými hříchy mají podle jeho názoru být krádež a zabití, šesté přikázání [„„Nesesmilníš゙“] nepovažuje za hřích; nedrží půst; neúčastní se mší).

Následují výslechy předem vybraných svědků: jejich nacionále, výpovědi, co viděli nebo slyšeli (i zprostředkované informace). Jsou využívány předem formulované otázky, zkoumá se, zda jsou svědci nestranní.

Následně je, na základě vlastní žádosti, vyslechnut obviněný (ff. 46r-48v). I on je dotazován na své osobní údaje. V této fázi se dovídáme alespoň dílčí biografické informace z jeho výpovědi: „ Řiká, že se jmenuje Wenceslao Superlling [sic], je vdovcem po Regině Isabel, rodák z Českého království a bydlištěm v mistě zvaném Nogueira u města Leirie, kde má svou továrnu na plátno, barvírnu a tkalcovnu; řiká, že mu je třicet šest let. "28 (fol. 46r). Od posledního údaje můžeme odvodit alespoň přibližně rok narození - $\mathrm{s}$ velkou pravděpodobností rok 1760.

Sperling argumentuje zaujatostí svědků (někteří byli jeho někdejšími zaměstnanci, které propustil, a proto ho z nenávisti očerňují), tvrdí, že byl od dětství, stejně jako jeho předci, římským katolíkem a že u víry setrval i poté, co Josef II. v roce 1781 vydal Toleranční patent (fol. 46v). Pod zápisem jeho výpovědi je pak vlastnoruční úhledný podpis v podobě Wenceslao Sperling (fol. 48r), který eliminuje jakékoliv prrípadné pochybnosti o jeho identitě. Řešení kauzy u inkvizice v Lisabonu bylo nakonec smírné: Sperling se kál, byl pokárán a upozorněn, že se prohřešků nesmí znovu dopouštět (ff. 49r-49v). Na závěr následuje opět jeho podpis (fol. 49v). Zde zápisky inkvizičního procesu končí.

Biskup Leirie (v té době jím byl výše zmíněný Manuel de Aguiar), k němuž se podle dalších údajů inkviziční kauza dostala, zaujal údajně rozumný postoj - z jeho popudu se

${ }^{17}$ HOFFMANNSEGG, J[ohann] C[enturius] Comte de - LINK, Heinrich Friedrich. Flore Portugaise ou Description de toutes les plantes qui croissent naturellement en Portugal. Avec Figures colorièes, cinq Planches de terminologie et une Carte. Berlin: Charles Fréderic Amelang, $1809-1840$.

${ }^{18}$ LINK 1801-1804.

${ }^{19} \mathrm{~K}$ chemickému výkladu dobového pojmu srov. SEKOTOVÁ 1976, s. 7.

${ }^{20}$ Manuel de Aguiar, 17. biskup Leirie (1790-1815), považovaný za jednoho z nejosvícenějších portugalských biskupů. Velká část jeho působení spadá do doby francouzských invazí do Portugalska. Srov. CRISTINO 2005, zvláště s. 49-50; ARAÚJO 2015.

${ }^{21}$ LINK 1801-1804, sv. 2, s. 18-19: ,, Vor Leiria hatte damahls ein Deutscher, Namens Sperling, eine Fabrik angelegt, mit übersaurer Salzsäure zu bleichen. Er zeigte mir manche Anstalten, wollte doch aber das wichtigste nicht sehen lassen, weil er behauptete, besondere Einrichtungen angebracht zu haben. Er erklärte, dass der Krieg ihn zwinge, seine Bude zu verschliessen, und, wie ich höre, hat die Anstalt bald nachher aufgehört. Er beging vielleicht den Fehler vieler Fabrikanten, mit zu kleinen Kapitalien anzufangen. Er war, wie er uns erzählte, einmahl in Gefahr gewesen, in die Hände der Inquisition zu fallen; er hatte sich nämlich mit deutscher Lebhaftigkeit oft an die Sonne gewandt, um ihm bey seinem Bleichen günstig zu seyn, und dieses wurde als Abgötterey dem Bischofe angegeben. Doch dieser, Don Manoel de Aguiar, war zu vernünftig, um es ihm übel zu nehmen, und liess sich durch seine Entschuldigung sogleich befriedigen. "

${ }^{22}$ LINK 1801-1804, sv. 3, s. 225: „Die Bleichfabrik vor Leiria, von einem Deutschen, Sperling, angelegt, hat nicht allein längst aufgehört, sondern man hat auch den Urheber aus dem Lande verwiesen. “

${ }^{23}$ Vydáno jako LINK, Henry Frederic. Travels in Portugal: and through France and Spain, with a dissertation on the literature of Portugal, and the Spanish and Portugueze languages. Trad. John Hinckley. London: T. N. Longman and O. Rees, 1801, zde s. 282.

${ }^{24}$ Vydáno jako LINK, M[onsieur ?]. Voyage en Portugal, depuis 1797 jusqu'en 1799. Paris: Levrault, Schoell et Cgnie, 1803, zde sv. 1., s. 369. Jiné francouzské vydání 1808 .

${ }^{25}$ Vydáno jako CLARA, Fernando (ed.). LINK, Heinrich Friedrich. Notas de uma viagem a Portugal e através de França e Espanha. Lisboa 2005, zde s. $174-175$

${ }^{26}$ Allgemeine geographische Ephemeriden 1804, díl 13, s. 206: „Die Bleichfabrik vor Leiria von einem Teutschen Namens Sperling angelegt, ist nicht nur längstens eingegangen, sondern ihr Urheber ist auch des Landes verwiesen worden. "

${ }^{27}$ ANTT, Lisboa, sign. PT/TT/TSO-IL/028/00413. Sumario contra Wenceslao Superlling [!] que tem hua fabrica junto a cidade de Leiria, 1796.

${ }^{28}$ Ibidem, fol. 46r: ,Disse chamar-se Wenceslao Superlling [!], viuvo de Regina Izabel, natural do Reyno de Boemia e morador no sitio de Nogueira junto a cidade de Leiria onde tem a sua fabrica de lançaria[,] tintoraria, e tecelagem, de idade que disse ser de trinta, e seis annos. " 
případ přestal řešit a pro Václava Sperlinga skončil aktuálně bez vážných konsekvencí. ${ }^{29}$

Nevíme však zatím přesně, jaké bylo pokračování jeho životních osudů, zda v Portugalsku setrval, nebo z něho odešel. Na základě citovaných - pozdějších - zpráv bychom se mohli domnívat, že Portugalsko opustil, a nejspíše ne zcela dobrovolně. ${ }^{30}$ Ještě $\mathrm{v}$ roce 1833 se $\mathrm{v}$ německém tisku objevuje krátká zpráva, že , továrna na bělení plátna založená u Leirie Němcem jménem Sperling již před nějakou dobou opět zanikla; její zakladatel byl ze země vykázán!'31 Může však jít také jen o převzatou informaci z Linkova spisu. Proč se ale málo aktuální informace objevuje s takovým časovým odstupem a proč zrovna $v$ tomto německém listě, je trochu záhadou. Snad to souvisí s tím, že Portugalsko je tam hojně citováno vzhledem k vleklému konfliktu mezi liberály a absolutisty a že je značná pozornost věnovaná i neutěšené portugalské ekonomice s př̀vahou britských zájmů. Situace 20. a 30. let 19. století má však málo společného s dobou přednapoleonskou, kdy se Václav Sperling v zemi usadil a tam působil.

$\mathrm{S}$ jistě nepř́liliš obvyklým př́jmením Sperling se ale v Portugalsku setkáváme i později. Nejen v další - tentokrát finanční - kauze vedené s Václavem (1806), nýbrž i v jiných - převážně ekonomických - a mnohem pozdějších souvislostech, které odkazují až k Brazílii. Zda však v těchto případech šlo o jeho přímé potomky, nebo jen o příbuzné, či o pouhou shodu prríjmení, nelze momentálně zjistit a bude nezbytné další studium této problematiky.

\section{Závěr}

Nově objevené dokumenty $\mathrm{v}$ zahraničním archivu v kombinaci s dostupnou dobovou i pozdější literaturou umožnily složit dílčí obrázek podnikatelských aktivit subjektů pocházejících z českých zemí v kontextu 18. století: činnost úspěšného náchodského podnikatele v obchodu s plátnem a zakladatele rafinerie koloniálního cukru v Novém Dvoře Františka Sperlinga bylo možné dát do souvislosti s dlouhodobým pobytem jeho bratra Václava v Portugalsku. Oba navázali na inovativní pokusy okruhu Ignáce Borna o bělení plátna chemickou cestou. Lze předpokládat, že v Portugalsku usedlý Václav mohl mít vliv i na dodávky surového brazilského cukru do bratrovy rafinerie, byt' o tom dokumenty zatím mlčí. Nicméně inkviziční spis vedený proti Václavovi vypovídá také o jiném (nejen dobovém) problému: složité integraci cizinců v ,jiném“ prostředí.

\section{Prameny:}

ANTT: Arquivo Nacional de Torre do Tombo, Lisboa, fond Tribunal do Santo Ofício, Inquisição de Lisboa, proceso 413, Sumario contra Wenceslao Superlling [!] que tem hua fabrica junto a cidade de Leiria, 1796, $51 \mathrm{ff}$. Dokument pod referenční sign. PT/TT/TSO-IL/028/00413 dostupný [online] z: https://digitarq.arquivos.pt/details?id=2300288 [poslední aktualizace 29. 4. 2011, cit. 2. 8. 2021].

MZA: Moravský zemský archiv v Brně (dříve Státní oblastní archiv, SOA Brno), fond G 445. Rodinný archiv Sylva-Taroucců, karton 20, lit. M, dopisy Luise Maciela, ff. 271-284.

\section{Literatura:}

Allgemeine geographische Ephemeriden 1804: Allgemeine geographische Ephemeriden, 13. Band. Weimar: Verlag des Landes-Industrie-Comptoirs, 1804.

ARAÚJO 2015: ARAÚJO, Vitorino da Silva. Um bispo segundo Deus ou Memorias para a vida de D. Manuel de Aguiar, $17^{\circ}$ Bispo de Leiria. Reedição facsimilada da edição original de 1885. Leiria: Textiverso, 2015. Tempos \& Vidas, 27.

BAĎURA 1964: BAĎURA, Bohumil. Apuntes sobre los orígenes del comercio vidriero entre Bohemia y México (1787-1839). Historica 9, 1964, s. 69-134. Česká verze viz Bohumil BAĎURA 2005: BAĎURA, Bohumil. K počátkům obchodu se sklem mezi Čechami a Mexikem. In: Porta Bohemica: sborník historických prací 3 (2005), Litoměřice, s. $120-194$.

BALCÁREK 1982: BALCÁREK, Pavel. Rodinný archiv Sylva-Taroucců (G 445), inventář, strojopis, Brno: SOA 1982.

BALCÁREK 1984: O arquivo da familia portuguesa Silva Tarouca na Checoslováquia. Ibero-Americana Pragensia 18, 1984, s. 167-175.

BINKOVÁ 1987: BINKOVÁ, Simona. Os países checos e a zona lusitana (Contactos e testemunhos dos séculos XVXVIII). Ibero-Americana Pragensia 21, 1987, s. 137-160.

BINKOVÁ 2017: BINKOVÁ, Simona. Česko-německý podnikatel v hledáčku portugalské inkvizice 1795-1796 (úvod do problematiky), nepublikovaná prezentace na 6. kolokviu Společnosti českých portugalistů, Centro Camões Praha, přednesená dne 17. 2. 2017.

BINKOVÁ 2018: BINKOVÁ, Simona. Manuel Teles da Silva a jeho vazby $\mathrm{k}$ Portugalsku a $\mathrm{k}$ portugalským zámořským územím skrze jeho knihovnu a archiv. Zprávy Vlastivědného muzea v Olomouci. Společenské vědy 316, 2018, s. 5-18.

CRISTINO 2005: CRISTINO, Luciano Coelho. A Diocese de Leiria - Fátima. In: JORGE, Virgolino Ferreira (ed.). Catedral de Leiria. Leiria: Diocese de Leiria - Fátima, 2005, s. 37-66.

ČÁP 1995: ČÁP, Jaroslav. Epizoda z historie náchodského textilu. In: ŠŮLA, Jaroslav (ed.). V proměnách času: sborník př́spěvků k padesátinám PhDr. Ladislava Hladkého. Hradec Králové: Gaudeamus, 1995, s. 31-40. Dissertationes historicae; č. 3/1995.

EHRMANN 1806: EHRMANN, Th[eophil] Fr[iedrich]. Neueste Länder- und Völkerkunde. Ein geographisches

\footnotetext{
${ }^{29}$ LINK 1801-1804, sv. 2, s. 18-19.

${ }^{30}$ LINK 1801-1804, sv. 3, s. 225.

${ }^{31}$ Neue Speyerer Zeitung, Nro. 165, 18. August 1833 [s. 3] pod heslem Portugalsko: „Die von einem Deutschen Namens Sperling angelegte Bleichfabrik bei Leiria ist längst wieder eingegangen; der Gründer derselben ward des Landes verwiesen! “
} 
Lesebuch für alle Stände. 1. Band, Weimar: Verlag des geographischen Instituts, 1806. Tento první svazek řady také jako Neueste Kunde von Portugal und Spanien: nebst einer allgemeinen Einleitung zur neuesten Länder-und Völkerkunde. Weimar: Verlag des F. S. Press Landes-Industrie-Comptoirs, 1806.

ERXLEBEN 1812: ERXLEBEN, Christ[ian] Polykarp Fried[rich]. Die böhmische Leinwandbleiche beschrieben mit den bekannten älteren und neueren Bleichmethoden verglichen, und als die vorzüglichste dargestellt in einer erklärenden Beschreibung der Bleichmethode des Verfassers und dessen Leinwandbleiche zu Landskron. Nebst einem Anhange chemischer Versuche zur Berichtigung der Theorie des Bleichens. Wien: Christian Kaulfuß und Carl Armbruster, 1812.

FRONĚK 2008: FRONĚK, Daniel. Výroba cukru na Zbraslavi - kolébka českého cukrovarnictví. Listy cukrovarnické a řepařské 124, 2008, č. 7-8 (červenec-srpen), s. 232-236.

LINK 1801-1804: LINK, Heinrich Friedrich. Bemerkungen auf einer Reise durch Frankreich, Spanien und vorzüglich Portugal. 3 sv., Kiel: Neue academische Buchhandlung, 1801-1804.

LIPPMANN 1890: LIPPMANN, Edmund O. von. Geschichte des Zuckers, seit den ältesten Zeiten bis zum Beginn der Rübenzucker-Fabrikation: ein Beitrag zur Kulturgeschichte. Leipzig: Max Hesse's Verlag, 1890.

Neue Speyerer Zeitung 1833: Neue Speyerer Zeitung, Nro. 165,18 . August 1833.

NEUMANN 1891: NEUMANN, K[arel] C[yril]. Nástin dějin průmyslu cukrovarnického v Čechách: Obdobi první. 1787-1830. Praha: Komitét pro uspořádání kolektivní výstavy cukrovarnické 1891.

NYPLOVÁ 1950: NYPLOVÁ, Zdenka. Kapitalistické začátky a krise zbraslavského cukrovaru. Český lid 37, 1950, č. 7/8, s. 164-168.

OPATRNÝ 1995: OPATRNÝ, Josef. El azúcar americano en la Europa del siglo XVIII. Jahrbuch für Geschichte Lateinamerikas - Anuario de Historia de América Latina 32, 1995, No. 1, s. 215-230.

POLIŠENSKÝ 1978a: POLIŠENSKÝ, Josef. Centro da Europa, Portugal e a América que leva o nome Brasil. IberoAmericana Pragensia 12, 1978, s. 9-18.

POLIŠENSKÝ 1978b: POLIŠENSKÝ, Josef. Uma desconhecida descrição de Praga e da Universidade de Praga do ano de 1707. Ibero-Americana Pragensia 12, 1978, s. 197-202.

PTÁČEK 1999: PTÁČEK, Josef. Druhá nejstarší rafinerie trrtinového cukru v Čechách v Novém Dvoře u České Skalice. Stopami dějin Náchodska: sbornik Státního okresního archivu Náchod 5, 1999, s. 189-191.

PTÁČEK 2012: PTÁČEK, Josef. Podnikatel František Sperling a rafinerie třtinového cukru $\mathrm{v}$ Novém Dvoře u České Skalice. Východočeské listy historické 29, 2012, s. $81-84$.

RIEGGER 1787: RIEGGER, Joseph Anton von. Von den Zuckerraffinerien in Böhmen. In: Materialien zur alten und neuen Statistik von Böhmen, IV. Heft, Leipzig und Prag: Kaspar Widtmann, 1787, s. 841-846.

ŘÍHA 1940: ŘÍHA, Oldřich. Počátky českého cukrovarnictví. In: STRÁNSKÝ, Josef B. (ed.). Z vývoje české technické tvorby: Sborník vydaný k 75. výroči založeni Spolku českých inženýrů v Praze. Praha: Spolek českých inženýrů v Praze, 1940, s. 133-135.

SEKOTOVÁ 1976: SEKOTOVÁ, Věra. Život a rodina Ch. P. Erxlebena, manufakturního podnikatele $\mathrm{v}$ Lanškrouně. Listy genealogické a heraldické společnosti v Praze = Acta genealogica et heraldica [řada 3], Sešit 12, únor 1976, s. 6-16.

SILVA-TAROUCA 1899: SILVA-TAROUCA, Franz Graf von. Die Silva's in Oesterreich. Ein Beitrag zur Geschichte dieses Hauses. Wien: Wilhelm Frick, 1899.

ŠTĚPÁNEK 2015: ŠTĚPÁNEK, Pavel. Mecenáši Josefa Mánesa. Portugalský rod Silva Tarouca a jeho vliv na českou kulturu. Olomouc: Univerzita Palackého v Olomouci, 2015.

WANNER 2008a: WANNER, Michal. Ostend'ané pod císařským praporem, 1714-1744. Část I. - Zrození a vzestup Všeobecné společnosti v Ostende. Historický obzor 19, 2008, č. 3-4, s. 50-66.

WANNER 2008b: WANNER, Michal. Ostend'ané pod císařským praporem, 1714-1744. Č́st II. - Soumrak a pád Všeobecné společnosti v Ostende. Historický obzor 19, 2008, č. 5-6, s. 111-126.

ZAVADILOVÁ 2001: ZAVADILOVÁ, Kateřina. Rozšiřreni kultu českých světců a Pražského Jezulátka v Portugalsku. Praha 2001. Diplomová práce. Univerzita Karlova, Filozofická fakulta.

\section{Elektronické zdroje:}

Direção-Geral do Livro, dos Arquivos e das Bibliotecas [online]. Dostupné z: https://digitarq.arquivos.pt/ [cit. 2. 8. 2021].

Diocese Leiria-Fátima [online]. Diocese Leiria-Fátima. Dostupné z: https://www.leiria-fatima.pt. Srov. zvláště CRISTINO, Luciano Coelho. A Diocese de Leiria-Fátima [Junho 12, 2015]. Dostupné z: https://www.leiria-fatima.pt/ breve-historia-da-diocese/ [cit. 31. 8. 2021].

\section{Simona Binková \\ Středisko ibero-amerických studií \\ Filozofická fakulta Univerzity Karlovy \\ nám. Jana Palacha $1 / 2$ \\ 11638 Praha 1}

